\title{
AgroTech investment and AgroSmart economy in Russia
}

\author{
Igor Aleksandrov ${ }^{1 *}$, Vitali Daroshka ${ }^{2}$, Alexander Isakov $^{3}$, Irina Chekhovskikh $^{4}$, Ekaterina \\ $\mathrm{Ol}^{4}$, and Elena Borisova ${ }^{5}$ \\ ${ }^{1}$ Petrozavodsk State University, Lenina 33, 185910, Petrozavodsk, Russia \\ ${ }^{2}$ Belarusian Trade and Economic University of Consumer Cooperatives, Oktyabrya Avenue 50, \\ 246012, Gomel, Belarus \\ ${ }^{3}$ The Bonch-Bruevich St. Petersburg State University of Telecommunications (SPbSUT), \\ Bolshevikov Avenue 22, 193232, St. Petersburg, Russia \\ ${ }^{4}$ St. Petersburg State University of Veterinary Medicine, Chernigovskaya 5, 196084, St. Petersburg, \\ Russia \\ ${ }^{5}$ St. Petersburg Branch of The Russian Customs Academy (named after V.B. Bobkov), Sofiyskaya, \\ 52A, 192241, St. Petersburg, Russia
}

\begin{abstract}
Abstract. The scientific article is devoted to the study of the formation of smart agriculture in Russia, taking into account the main trends in the development of the digital economy, as well as the characterization of the most important points of development of the national AgroSmart economy. Given the escalating problem of sanctions and the chronic nature of Russia's food wars with both near and far abroad countries, the issue of forming a new organizational and technological paradigm in the agro-industrial complex is a vital step to ensure the wellbeing of the whole society. Currently, in the agro-industrial complex of the Russian Federation there is a significant technological gap in terms of ensuring the smart growth of agribusinesses based on digital technologies and solutions, which negatively affects its production, export potential and financial condition. The validity and reliability of the results of scientific research was achieved through the correct construction of the logic and research scheme. Scientific and practical studies of Russian and foreign scientists in the field of agricultural business development, digital economy, public administration in the field of agriculture were used as the methodological and fundamental basis of the study.
\end{abstract}

\section{Introduction}

Digitalization of the agricultural sector is an objective factor in the successful construction of a new, digital economy in Russia and the formation of a smart growth trajectory for such basic, "terrestrial" sub-sectors as crop production and animal husbandry. These basic subsectors are not only a platform for the entire sphere of agribusiness, but also directly affect the food, demographic and economic security of the country. Today, businesses in the agroindustry complex face a new point of choice: "maintain the traditional business model

\footnotetext{
* Corresponding author: a7830298@gmail.com
} 
of personal responsibility for portfolio management" of agricultural activities (functional and species centers of individual responsibility), or move to a new format for organizing and managing operational business processes and agribusiness strategy using the latest technologies based on the principles of artificial intelligence [1].

Interest in the smart organization of business processes in the agroindustry complex arose relatively recently - in $1970-1980$, which is associated with the technical complexity of introducing information systems into such a multifactorial and difficult-to-predict field of behavior of biological assets as agroindustry complex, although the ideas of organizing agriculture using high technologies were laid at the beginning of the 20th century (tentatively in 1920-1930). The first practical application of information technologies in the agroindustry complex was the use of the JPS system in the formation of a fertilizer application map in Texas in 1988. The real wide distribution of solutions for digitalizing business models of agribusiness was in 2002-2010. with the development of broadsheet Internet, Wi-FI network, the development of the JPS system [2 -4].

Thus, the transformation of business models of agroindustry enterprises is a vital factor in launching the smart growth trajectory of such basic, "terrestrial" sub-sectors as crop production and animal husbandry, which directly affect the food, demographic and economic security of the country. In addition, one should not forget about the problem of conflicts of goals that arise among farmers in the event of an increase in the extensive productivity of agricultural resources (soil erosion, water pollution, deforestation) while trying to ignore the progress of the digital economy, which will further aggravate the lag of the Russian Federation in the world rankings of agricultural leaders [5, 6].

\section{Smart agriculture: concept, genesis, basic business models}

The demand for the development of smart development of the agricultural sector was dictated by both purely pragmatic and social reasons:

- group of socio-economic challenges: urbanization (more than $45.7 \%$ of the world will live in cities by 2025); uneven income growth (according to IMF and UN data, by 2025 income growth is expected to be $3.0-10.0 \%$ depending on the region); increasing environmental problems;

- value reasons dictated by the interests of society: demand for semi-finished products and products $\mathrm{HoReCa}$; promotion of healthy nutrition, personal diets; interest in halal products; personalization and customization of food production and sales services;

- Technological reasons: food design and food engineering (including genetic modifications of food); new business models for the organization of production and sale of products (home farms, crowd-farming, food-sharing, online services for ordering the production and delivery of food); urban farming (city farming).

The starting point of digitalization of the agricultural sector in the Russian Federation is traditionally administrative levers in the form of state federal and national sectoral programs. So, according to the decision recorded in the Decree of the President of Russia "On National Goals and Strategic Objectives for the Development of the Russian Federation for the Period until 2024" of May 7, 2018, the task of incorporating digital technologies and platform solutions based on artificial intelligence into the agroindustry complex was set. Subsequently, based on the requirements of the Food Security Doctrine of the Russian Federation (approved by Decree of the President of the Russian Federation on January 21, 2020 No. 20) and the Program "Digital Economy of the Russian Federation" (Decree of the Government of the Russian Federation dated July 28, 2017 No. 1632-R) developed a departmental project "Digital Agriculture" for the period 2019-2024. Within the framework of this project, a number of independent areas of digitalization of the 
agroindustry complex: "Smart Farm"; Smart Field; Smart Herd; "Smart Greenhouse"; "Smart processing"; Smart Warehouse; Smart AgroOfice [7, 8].

Interesting for the study of the scale of problems is the results of an assessment of the innovative development of the agricultural sector of the Russian Federation for 2015-2019. PWC specialists, according to which Russian agribusiness among world leading countries in the field of agricultural sector occupies a basic level.

Despite the obvious advantages of harmonizing business models with the best global practices, agribusiness enterprises are for the most part one of the most conservative categories of the national economy, and the motivation of management to reform the agribusiness business model is a difficult and long-term task. To study the problems and prospects of implementing digital solutions in the architecture of the business model of agroindustry enterprises, we identified the following participants who were classified on the basis of the requirements of the Codex Alimentarius.

- business model of pure producer (B2B-model) - enterprises of this group focus exclusively on production business processes and concentrate resources and efforts on production of agricultural products;

- business model "from the field to the counter" - enterprises of this group include business processes of commercial and logistical interaction with wholesale and retail trade segments (FMCG-segment), as well as representatives of the restaurant and hotel business (segment HoReCa);

- business model "vertically integrated agroindustry holding with its own commercial network" - enterprises of this group include a full cycle of production and sale of products in the format "from field to fork" [9-11].

For the Russian Federation, which is critically close to the transition to the level of development of advanced business practices, experts in the field of agroindustry complex should clearly determine the goals and directions of the development of agroindustry complex based on digital technologies. Thus, AgFunder experts identify three main groups of innovative technologies that ensure an early transition from traditional, physical business models of agribusiness to digital solutions:

1. Industrial technologies "from farm to counter" - a group of digital technologies that is responsible for the quality and safety of agricultural products in the process of their cultivation, collection, storage and transportation to places of sale.

2. Consumer technologies "from counter to plate" - a group of digital technologies responsible for minimizing physical, chemical and biological losses of the value of agricultural products in the process of storage and sale to the final consumer.

3. Transition (infrastructure) is a group of physical and digital technologies that provides the most effective implementation of digital practices for organizing and managing business processes in the field of agribusiness [12 - 13].

To understand the relevance and directions of the development of digitalization practices and the transfer of agribusiness to the artificial intelligence mechanism, we will consider the state of the investment market in agricultural technology projects (including startups) in the world and the Russian Federation in 2014-2019 (Table 1).

As can be seen from the table in the Russian Federation, there is a significant lag behind the world level of innovative activity of the agricultural sector, which indicates the need to take immediate measures to intensify the construction of an innovative trajectory for the development of agribusiness.

Table 1. Investments in Agrotechnological projects (including start-ups) in the world and the Russian Federation in $2014-2019$ [14-16]. 


\begin{tabular}{|l|r|r|r|r|r|r|}
\hline \multicolumn{1}{|c|}{ Performance } & 2014 & 2015 & 2016 & 2017 & 2018 & 2019 \\
\hline $\begin{array}{l}\text { Total investments in } \\
\text { agro-technological projects } \\
\text { (including startup projects) } \\
\text { in the world, million dollars. } \\
\begin{array}{l}\text { USA } \\
\text { Including: }\end{array}\end{array}$ & 5700 & 8800 & 8600 & 11500 & 20800 & 19800 \\
\hline $\begin{array}{l}\text { 1.1 Industrial technologies } \\
\text { "from farm to counter" }\end{array}$ & 2800 & 5800 & 5100 & 6500 & 13200 & 12000 \\
\hline $\begin{array}{l}\text { 1.2 Consumer technologies } \\
\text { "from counter to tray" }\end{array}$ & 2900 & 3000 & 3400 & 4800 & 7500 & 7800 \\
\hline $\begin{array}{l}\text { 2. Total investments in } \\
\text { agrotechnological projects } \\
\text { (including startup projects) } \\
\text { in the Russian Federation, } \\
\text { million dollars. USA } \\
\text { Including: }\end{array}$ & - & - & 149.6 & 150.7 & 159.4 & 220.3 \\
\hline $\begin{array}{l}\text { 2.1 Purchase of machinery } \\
\text { and equipment }\end{array}$ & - & - & 93.4 & 117.7 & 105.7 & 151.9 \\
\hline $\begin{array}{l}\text { 2.2 Acquisition of Software } \\
\text { Solutions }\end{array}$ & - & - & 22.3 & 13.6 & 10.0 & 22.2 \\
\hline $\begin{array}{l}\text { 2.3 R\&D narrow } \\
\text { specialization projects }\end{array}$ & - & - & 31.4 & 12.2 & 19.6 & 30.4 \\
\hline 2.4 Engineering Innovative activity of \\
\hline $\begin{array}{l}\text { 3. Innoindustrycomplex } \\
\text { agron } \\
\text { organizations }\end{array}$ & - & - & 16.5 & 11.5 & 13.7 & 20.0 \\
\hline $\begin{array}{l}3.1 \quad \text { Worldwide (average } \\
\text { estimate) }\end{array}$ & 7.7 & 10.6 & 12.4 & 14.2 & 15.6 & 17.1 \\
\hline 3.2 Russian Federation & - & - & 4.0 & 3.7 & 5.4 & 5.8 \\
\hline
\end{tabular}

\section{Main instruments for financing investments in AgroTech projects in the Russian Federation}

An important factor in the successful implementation of digitalization projects of agricultural enterprises is the balance and market principles of providing financing: the success of an innovative project, especially in such risky activities as agriculture, largely depends on the investor's interest and his requirements. Data on the composition and structure of funding sources for digital business models of agroindustry enterprises in the Russian Federation for 2016-2019. are given in Table 2.

As can be seen from the data of Table 3 in the Russian Federation, agroindustry enterprises mainly use their own funds to finance innovative projects in terms of digitization of their own business models: on average, 9730.8 million rubles were accounted for this source of financing, or $53.5 \%$, other sources of financing were in second place - 5653.3 million rubles, or $30.3 \%$. In official statistics, there is no specificity in terms of this source, but based on business practices, these may be previously undistributed amounts of profit, depreciation deductions in the form of accumulated funds, which leads to the conclusion that the share of own funds in financing digitization projects is even higher. In addition, it should be noted that since 2019, business cooperation in the field of 
agroindustry complex with banks has also taken the path of their integration within the framework of digital products and services (Table 3).

Table 2. Composition and structure of sources of financing of digital business models of Agroindustry enterprises in the Russian Federation for 2016 - 2019 [14 - 16].

\begin{tabular}{|l|c|c|c|c|}
\hline \multicolumn{1}{|c|}{ Performance } & 2016 & 2017 & 2018 & 2019 \\
\hline $\begin{array}{l}\text { 1. Total amount of financing of } \\
\text { agrotechnological projects (including } \\
\text { startup projects) in the Russian } \\
\begin{array}{l}\text { Federation, million rubles. } \\
\text { Including: }\end{array}\end{array}$ & 15073.6 & 15806 & 21960.5 & 20394.5 \\
\hline $\begin{array}{l}\text { 1.1 Own sources of investment } \\
\text { financing }\end{array}$ & 9360.7 & 7378.7 & 10008.2 & 12175.5 \\
\hline $\begin{array}{l}\text { 1.2 Means of federal } \\
\text { agroindustrycomplex development } \\
\text { programs }\end{array}$ & 1552.6 & 1704.7 & 1029.4 & 3344.7 \\
\hline $\begin{array}{l}\text { 1.3 Means of regional budgets of the } \\
\text { constituent entities of the Russian } \\
\text { Federation }\end{array}$ & 1205.9 & 54.4 & 141.3 & 1937.5 \\
\hline $\begin{array}{l}\text { 1.4 Venture funds and similar (non) } \\
\text { commercial entities }\end{array}$ & 0.0 & 0 & 0 & 224.3 \\
\hline 1.5 Foreign Investment & 30.1 & 313.6 & 78.2 & 81.6 \\
\hline 1.6 Other sources of funding & 2924.3 & 6354.6 & 10703.4 & 2630.9 \\
\hline 2. Share of funding sources & 100.0 & 100.0 & 100.0 & 100.0 \\
\hline $\begin{array}{l}\text { 2.1 Own sources of investment } \\
\text { financing }\end{array}$ & 62.1 & 46.7 & 45.6 & 59.7 \\
\hline $\begin{array}{l}\text { 2.2 Means of federal } \\
\text { agroindustrycomplex development } \\
\text { programs }\end{array}$ & 10.3 & 10.8 & 4.7 & 16.4 \\
\hline $\begin{array}{l}\text { 2.3 Means of regional budgets of the } \\
\text { constituent entities of the Russian } \\
\text { Federation }\end{array}$ & 8.0 & 0.3 & 0.6 & 9.5 \\
\hline $\begin{array}{l}\text { 2.4 Venture funds and similar (non) } \\
\text { commercial entities }\end{array}$ & 0.0 & 0.0 & 0.0 & 1.1 \\
\hline 2.5 Foreign Investment & 0.2 & 2.0 & 0.4 & 0.4 \\
\hline 2.6 Other sources of funding & 19.4 & 40.2 & 48.7 & 12.9 \\
\hline $\begin{array}{l}\text { 3. Share of market sources of } \\
\text { financing,\% (p.1 + p.1.4 + p.1.5 )/p.1 }\end{array}$ & 62.3 & 48.7 & 45.9 & 61.2 \\
\hline
\end{tabular}

Table 3. Digital products of cooperation between agribusiness and banks $[17,18]$.

\begin{tabular}{|c|c|}
\hline $\begin{array}{c}\text { Digital } \\
\text { Products/Services }\end{array}$ & Digital Product/Service Characteristics \\
\hline $\begin{array}{l}\text { 1. Smart Farm } \\
\text { Comprehensive Product }\end{array}$ & $\begin{array}{l}\text { Product/instrument supplier: considered as potential partners of } \\
\text { Sberbank PJSC, VTB Bank PJSC, Rosselkhozbank JSC. } \\
\text { Product concept: provision of information spaces and capacities of } \\
\text { the bank for digitalization of business processes on the farm and } \\
\text { the option of remote management. The bank receives a } \\
\text { commission for using its digital infrastructure, the farmer saves } \\
\text { money on creating his own digital solutions. } \\
\text { Expected products: drones-monitors for precision farming, } \\
\text { transport control via GPS, monitoring the state of plants and } \\
\text { animals through sensors. } \\
\text { Implementation dates: } 2019-2025\end{array}$ \\
\hline 2. AIOT platforms & $\begin{array}{l}\text { Product/instrument supplier: considered as potential partners of } \\
\text { Sberbank PJSC }\end{array}$ \\
\hline
\end{tabular}




\begin{tabular}{|l|l|}
\hline & $\begin{array}{l}\text { Product concept: predictive analytics and artificial intelligence to } \\
\text { evaluate the effectiveness of the farm's business model, search for } \\
\text { hidden dependencies, early detection of crop problems, animal } \\
\text { health, smart energy consumption. } \\
\text { Implementation dates: } 2021-2025\end{array}$ \\
\hline
\end{tabular}

\section{The main directions of the development of the Agro-Tech market in Russia}

Agribusiness in the Russian Federation is recommended to pay attention to the following areas of smart development of the agricultural sector, based on the use of the artificial intelligence mechanism:

1. Precision farming - a set of measures aimed at organizing the rational operation of the agribusiness land bank by compiling an interactive map of the terrain and features of the soil structure, its category and fertility score using light unmanned aerial vehicles (UAV), which makes it possible in an interactive form to generate technological landscape maps of crop rotation and determine the most suitable crops in real time (accelerated land management due to prevention of land fund downtime) [19].

According to the author, this direction is critically relevant for territories with a mixed landscape or for enterprises with a geographically distributed land bank not only within the boundaries of one administrative unit, but even different subjects of the federation (for example, PJSC Cherkizovo owns a land bank distributed in 7 different administrative units and 3 climatic zones). According to the research of V. Yakushev, accurate agriculture in the Russian Federation is used by about 50 large holdings of the country, and the volume of agricultural land covered by coordinate agriculture is no more than $5-7 \%$

According to regional ranking on the use of elements of precision agriculture and precision animal husbandry for 2018, conducted by the Center for Forecasting and Monitoring and the Department of Scientific and Technological Policy and Education of the Ministry of Agriculture of Russia, the leaders were agribusiness of the Krasnodar Territory - 189 units., Voronezh region - 182, Nizhny Novgorod region - 144.

Examples of the successful launch of smart farming projects based on an artificial intelligence management mechanism and their expected economic effect are presented on the example of the Smart Combine project implemented, which was prepared by the Cognitive Agro Pilot project team with the financial support of Sberbank PJSC - a system of autonomous management of agricultural machinery - a combine harvester, tractor, sprayer - with remote monitoring function, the economic effect of which is to reduce the cost of grain production by $3,0-5.0 \%$ and double reduction of losses during its cleaning.

2. Smart farms are partially or fully automated complexes for raising poultry, cattle, pork, whose business processes of raising animals are controlled remotely by an operator using artificial intelligence systems. In such a complex, monitoring of the condition of the main and repair livestock or poultry is carried out remotely on the basis of sensors on their state of health, as well as photographic, video recording cameras and various contactless feed supply systems, water supply, and access system for unrelated content. The leaders in the use of elements of accurate animal husbandry by the number of farms in the regions were: Sverdlovsk Region - 83, Republic of Bashkortostan - 68, Udmurt Republic - 67 [28].

The first example of the successful implementation of such a farm format is the construction of Cherkizovo PJSC of a robotic turkey growing complex in Tambov, together with the Spanish investor Grupo Fuertes (Tambov Turkey project). The goal of the project is to maximize the automation of the process of growing and tracking the vital indicators of turkeys using Neuromation systems (a computer vision system analyzes the gain in the 
weight of turkeys, evaluates body indicators using contactless sensors, and then forms a scenario of further diet and day mode for most livestock.

3. Smart greenhouses - a revolutionary technology of hybrid technical and organizational solutions for the construction of small greenhouse forms within cities or the creation of large-scale greenhouse complexes with an intelligent plant life support parameter management system with the function of zoning climatic, feeding and water supply schemes in real time.

In world practice, examples of successful collaboration between urban management and agroindustry complex are business models of vertical farms controlled by artificial intelligence in the framework of projects of "smart (adaptive) urban spaces" (AeroFarm (USA), TokyoSalad (Yaopnia), RusECO (Moscow, 2019), AgroTehPharm (Yekaterinburg, 2020), IliOtek.

One of the successful examples of the implementation of smart greenhouses in the Russian Federation is the iFarm project, created in Novosibirsk in 2017. Currently, under the leadership of the team, there are three translucent and four vertical trusses with a total area of more than $1750 \mathrm{~m} 2$. The estimated cost of the greenhouse is 10 million rubles. (a fully equipped multi-tier vertical greenhouse with an area of $200 \mathrm{~m}^{2}$ ), the payback of the project is an average of 3 years.

\section{Conclusion}

According to the results of the scientific study, the problems of the development of digital business models of agroindustry enterprises in domestic and foreign practice were studied. In the world, interest in digitalization of business models of agroindustry enterprises is associated with global problems of food shortages and climate problems; increasing urbanization and the aggregate population of the world; exhaustion of growth resources through the II Green Revolution; increasing demand for clean food and interest in personalizing the food and service market.

The digitalization of the agroindustry complex in Russia follows its original path, which is very different from world practices in a number of aspects: firstly, the main motivating factor in the digitalization of agroindustry enterprises is the state decisions of the first persons; secondly, the sphere of agroindustry complex in the Russian Federation is very dependent on subsidies and subsidies from budgets of different levels; thirdly, there is a complex and heterogeneous structure of agricultural land in the territory of the Russian Federation; fourthly, the low share of waste processing in the field of agroindustry complex, and, as a result, its high material and energy intensity; fifth, the lag of Russian agroindustry enterprises from the global practice of introducing digital solutions.

For the Russian Federation, which is critically close to the transition to the level of development of advanced business practices, AgFunder distinguish three main groups of innovative technologies: industrial technologies "from farm to counter"; consumer technologies "from the counter to the plate"; Transitional (infrastructure) technologies that provide the most efficient implementation of digital practices in the organization and management of business processes in the field of agribusiness. In accordance with the recommendations of specialists of the consulting agency PWC CIS, agribusiness in the Russian Federation is recommended to pay attention to the following areas of smart development of the agroindustry complex, based on the use of the artificial intelligence mechanism: accurate agriculture; smart farms; smart greenhouses.

\section{References}


1. A.A. Aitpaeva, Bulletin of Astrakhan State Technical University. Series: Economics, 3 (2019)

2. D.C. Booklagin, Intern. Research Jrn, 2 (2021)

3. N. Chergui, M.T. Kechadi, M. McDonnell, The impact of data analytics in digital agriculture: A review, International Multi-Conference on: Organization of Knowledge and Advanced Technologies, OCTA 2020 (2020)

4. S. Fountas, B. Espejo-Garcia, A. Kasimati, N. Mylonas, N. Darra, IT Professional, 22 (2020)

5. É.L. Bolfe, L.A. de C. Jorge, I.D. Sanches, A.L. Júnior, C.C. da Costa, et al, Agriculture (Switzerland), 10(12) (2020)

6. C. Florey, J. Hellin, J. Balié, Enterprise Development and Microfinance, 31(2) (2020)

7. I.A. Ganieva, N.E. Bobrov, Achievements of science and technology of the agroindustrial complex, 33, 9 (2019)

8. S.B. Ognivtsev, International Agricultural Journal, 2 (2019)

9. J. Ingram, D. Maye, Frontiers in Sustainable Food Systems, 4 (2020)

10. A. Lajoie-O’Malley, K. Bronson, S. van der Burg, L. Klerkx, Ecosystem Services, 45 (2020)

11. A.M. Pukach, Bulletin of agrarian science, 4 (2019)

12. O.V. Shumakova, O.N. Kryukova, Bulletin of Agrarian Science, 1 (2021)

13. A.A. Tuskov, Models, systems, networks in economics, technology, nature and society, 1 (25) (2018)

14. Indicators of innovation: 2018: statistical collection (National. research. un-t "Higher School of Economics", 2018)

15. Indicators of innovation: 2019: statistical collection (National. research. un-t "Higher School of Economics", 2019)

16. Indicators of innovation: 2020: statistical collection (National. research. un-t "Higher School of Economics", 2020)

17. A.T. Kenzhabaev, Economics and business: theory and practice, 1-1 (2021)

18. C. Fuchs, Marx in the Age of Digital Capitalism (Boston; Brill, 2016)

19. T. Ravis, B. Notkin, Berkeley Planning Journal. University of California, Berkeley (2020)

20. M. Shepherd, J.A. Turner, B. Small, D. Wheeler, Journal of the Science of Food and Agriculture, 100(14) (2020) 